\title{
Trace Metals in Fine and Respirable Ambient Air Particulates on Trinidad's West Coast
}

\author{
Himawatee Baboolal, Derrick Balladin, Samantha Chadee \\ Environmental Studies and Research Programme, University of Trinidad and Tobago, Arima, Trinidad and Tobago \\ Email: hemas99@yahoo.com
}

How to cite this paper: Baboolal, H., Balladin, D., \& Chadee, S. (2020). Trace Metals in Fine and Respirable Ambient Air Particulates on Trinidad's West Coast. Journal of Geoscience and Environment Protection, $8,61-81$.

https://doi.org/10.4236/gep.2020.86006

Received: May 14, 2020

Accepted: June 26, 2020

Published: June 29, 2020

Copyright ( 2020 by author(s) and Scientific Research Publishing Inc. This work is licensed under the Creative Commons Attribution International License (CC BY 4.0).

http://creativecommons.org/licenses/by/4.0/

\begin{abstract}
The paper analyzed the concentrations of trace metals in fine and respirable particulates (fine- $\mathrm{PM}_{1}$ and $\mathrm{PM}_{2.5}$; respirable- $\mathrm{PM}_{10}$ ) to determine baseline concentrations in the ambient air and the factors impacting its distribution such as land use and time of year when levels may be concerning to public health. Measurements of particulates along with meteorological parameters were made at four sites over the heavily populated west coast of Trinidad $\left(10^{\circ} 32^{\prime} \mathrm{N}, 61^{\circ} 18^{\prime} \mathrm{W}\right)$ during March '15-May ' 16 , representing rural, urban, mixed background and industrial land uses. The study found mean levels of trace metals to be highest at the industrial and urban stations. Public health exceedances (referenced to the Canadian AAQ public health standards (Ontario-MoE, 2012)) were measured for beryllium, cadmium, chromium, iron, manganese and nickel (in $\mathrm{PM}_{10}$ ). Iron, manganese and nickel, most associated with particulates at the industrial station, were in frequent exceedance. Beryllium-concentrated in coarse PM $\left(\mathrm{PM}_{2.5-10}\right)$ with only a single measured exceedance at the mixed background station likely poses minimal threat to the health of the nearby population. Cadmium-concentrated in fine PM which peaked once only at the rural station was likely due to an irregular event within a narrow timeframe during the time of sampling. Iron and manganese were frequently above the Canadian public health threshold, but predominated in the coarse PM fraction, suggesting localised sources. Nickel, concentrated in the fine PM fraction, was frequently in exceedance particularly at the industrial station. Cadmium and nickel are genotoxic and should be regulated in order to reduce the burden of toxic carcinogens to which the population can be exposed.
\end{abstract}

\section{Keywords}

Ambient Air Pollution, Fine and Respirable Particulates, Trace Metals 


\section{Introduction}

Ambient air particulates can act as a medium of transport for a myriad of adsorbed organic and inorganic chemicals, trace metals, microscopic biologicals and viruses from various sources. Respirable particulates $\left(\mathrm{PM}_{10}\right)$ containing contaminants can by-pass the natural defenses of the human respiratory system and enter the body through varied pathways, including inhalation. Trace metals entering the lungs through inhalation can cause harm to human health both from their physical presence inside the lungs, obstructing gas exchange, and leaching of adsorbed metals into the cells and bloodstream (Geiger \& Cooper, 2010; DEFRA, 2008; European Commission, 2001).

Pollutants emitted in the air eventually find their way down and can be deposited in the surface water (rivers, ponds, reservoirs, lakes) and marine sediments. In Trinidad and Tobago ( $\mathrm{T} \& \mathrm{~T}$ ), high levels of $\mathrm{Al}, \mathrm{Fe}$, and $\mathrm{Zn}$ have been found in the coastal and marine sediments off Port-of Spain (Al-39420 $\mu \mathrm{g} / \mathrm{g}$; Fe-45640

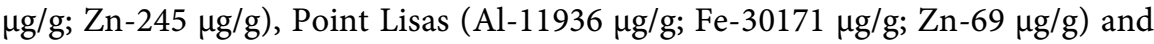

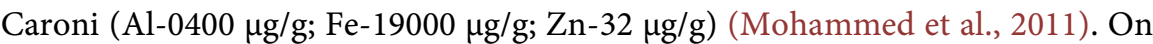
Trinidad's west coast, levels of $\mathrm{Cd}, \mathrm{Mn}, \mathrm{Ni}, \mathrm{Pb}$ and $\mathrm{Zn}$ in descending order (measured in marine sediments and biota) were found to pose significant ecological risk assessed from the potential impact and mobility in the environment (Norville, 2019).

Toxicological and epidemiological studies to establish disease causality and revision of these thresholds for public health protection have been ongoing since international protections under variations of the Clean Air Act were adopted by several countries (Balluz et al., 2007; Bruske et al., 2010; Lepeule, Laden, Dockery, \& Schwartz, 2012). As air pollution can effectively be controlled at the point of emission (European Commission, 2001), the regulation of the concentration of respirable particulates and contaminants contained in them (e.g. trace metals) is a common feature in the pollution regulation and legislative arsenal of many states and pollution control agencies, including Trinidad and Tobago.

The concentrations of trace metals measured in this study were analysed to determine baseline concentrations in the ambient air and the factors impacting their distribution e.g. particular land uses, time of year and/or geographical areas where levels pose a threat to public health. Exceedance levels, are defined as the frequency of sampled trace metals levels in $\mathrm{PM}_{10}$ (measured over24 hrs) exceeding the local standards (Environmental Management Authority of Trinidad and Tobago, 2014) and/or international guidelines (Ontario-MoE, 2012) identified for protection of public health.

\section{Literature Review}

Several epidemiological studies have found a causal relationship between levels of air pollution (respirable particulates, toxic levels of trace metals, pollutant gases) and ill health, respiratory and cardiovascular disease, cancer and increased 
mortality (Dockery et al., 1993; Grahame \& Schlesinger, 2010; Bruske et al., 2010; Pinto, Soares, Couto, \& Almeida, 2015). Inhalation exposure to ambient air pollution is usually a chronic, long-term situation that can start very early in life; factors which make its effects so detrimental to public health. Locally, levels of particulates in ambient air have already been linked to increased hospital admissions for asthma and respiratory related illnesses in children (Monteil et al., 2005; Gowrie, Agard, Barclay, \& Mohammed, 2016).

Physical assessment of fine and respirable particulates to better estimate the "dose" of trace metals from inhalation exposure have shown that this depends on source contributions and size of PM which carries it. In Detroit, Michigan (Utsunomiya, Jensen, \& Keeler, 2004), fine and ultrafine curbside particulates examined using high-angle annular dark-field scanning transmission electron microscopy (HAADFSTEM) techniques found most trace metals in the 0.01 $1.0 \mu \mathrm{m}$ PM fraction, which has the longest atmospheric residence time (more than 100 days) in ambient air.Trace metals on particulates in this size range have increased chemical reactivity owing to the size of nanoparticles on which they are adhered/adsorbed. Curbside trace metals in particulates from a busy intersection in Delhi, India were much higher $\left(\mathrm{PM}_{2.5}\right.$ daily means-286.23 \pm $41.1 \mu \mathrm{g} / \mathrm{m}^{3}$ ), mostly originating from diesel exhaust and vehicle "wear and tear" (Khanna, Khare, \& Gargava, 2015), i.e. from a mixture of gas-phase fine and coarse particulates. In the Caribbean, a lot of the fine PM comes in from transboundary Sahara dust, which has a similar trace metal composition to crustal dust, but may contain other contaminants (Garrison et al., 2006; Griffin, 2007; Garrison et al., 2010).

The impacts of contamination are manifested both on the environment as well as on human health and biodiversity. Ecologically, trace metal contamination can cause major disruption to the natural biogeochemical cycles by affecting the micro-geochemistry of microbiota and plankton (Mahowald et al., 2018). With regard to its impact on humans, trace metals in the body above toxic thresholds impact at the cellular and metabolic levels. The finer the inhaled particulates, the better its ability to penetrate deeper into the lungs.

According to assessments in China (Zhang, Jin, Johnson, \& Gies, 2016) and the European assessment (European Commission, 2001), cadmium and arsenic compounds are enriched in the fine particle mode about or below $1 \mu \mathrm{m}$ and, consequently, can penetrate deeply into the respiratory system and have long residence times in the atmosphere. Arsenic was found more abundantly in fine particles $\left(\mathrm{PM}_{1}\right)$; the arsenic found in the coarser PM $(5-10 \mu \mathrm{m}$ aerodynamic diameter) came from dust and soils and was less prevalent. In the UK, independent evaluation of epidemiological studies containing well explained histological evidence to support "tolerable level” recommendations for trace metals and metalloids (As, Be, Cr and Ni) in ambient air standards (DEFRA, 2008) suggested two threshold tiers; a cancer risk threshold and a non-cancer threshold, with a preference to regulate towards the latter. 
The mechanism for cancer induction from insoluble particulate nickel compounds, including the sulphide and sub-sulphide inhalation exposure, is through the release of reactive oxygen species from phagocytic cells (DEFRA, 2008). These insoluble forms of nickel have been shown to be more carcinogenic than soluble nickel and in vitro studies have demonstrated that they induce greater intracellular free radical production than soluble nickel salts. There is evidence that genotoxic effects of nickel compounds may be indirect, through inhibition of DNA repair systems. This possibly reflects the ability of nickel to form complexes with the amino acid histidine which may then take part in redox reactions.

Similarly, chromium has a projected metabolic pathway for inhaled chromium containing particles or fumes containing carcinogenic hexavalent chromium (Cr-IV). It is reduced to Cr-III by low molecular weight reductants such as ascorbic acid and glutathione in epithelial lining fluid, any remaining Cr-VI is transported into cells via the anion transport channel along a concentration gradient and inside the cell reacts with reductants, which leads to the formation of reactive oxygen species (DEFRA, 2008).

\section{Methods and Procedures}

Trinidad and Tobago (population $1.3 \mathrm{M}$ ) is a twin island state located at the bottom of the Caribbean chain, resting on the southern periphery of the Atlantic hurricane belt (between 10.4 to $11.35 \mathrm{~N}$ lat, -60.52 to $-61.93 \mathrm{~W}$ long). The state enjoys a tropical maritime climate with two distinct seasons (wet and dry), an annual rainfall of $2200 \mathrm{~mm}$ and temperatures in the range of $22^{\circ} \mathrm{C}-33^{\circ} \mathrm{C}$ (mean $26.5^{\circ} \mathrm{C}$ ) with predominant winds blowing from the $\mathrm{NE}$ - the northeast trade winds. It has an industrialised economy, based on natural gas and petrochemicals and a relatively high pre-COVID-19 per capita GDP of USD16,844 (2018). Trinidad is the more industrialised island of the twin island state, tourism being the predominant economic activity in Tobago.

\section{Experimental and Numerical Setting}

Ambient air sampling was undertaken at four sampling sites along Trinidad's west coast, selected using the land use criteria (each representative of areas with urban, rural, industrial and mixed use/background as the dominant land use within a $1 \mathrm{~km}$ diameter), accessibility and security (illustrated in Figures 1 (a)-(d)). Aerosolised respirable particulates were measured using 24 hour measurement protocols every $6^{\text {th }}$ day from March 2015-May 2016 using modular high precision low volume gravimetric particulate samplers at the four sites for simultaneous sampling. Air quality sampling stations were located at:

- URBAN. Port of Spain (Station 3): 10.660N lat, 61.520W long;

- RURAL. Waterloo (Station 4): 10.481N lat, 61.465W long;

- MIXED BACKGROUND. San Fernando (Station 1): 10.289N lat, 61.441W long; 

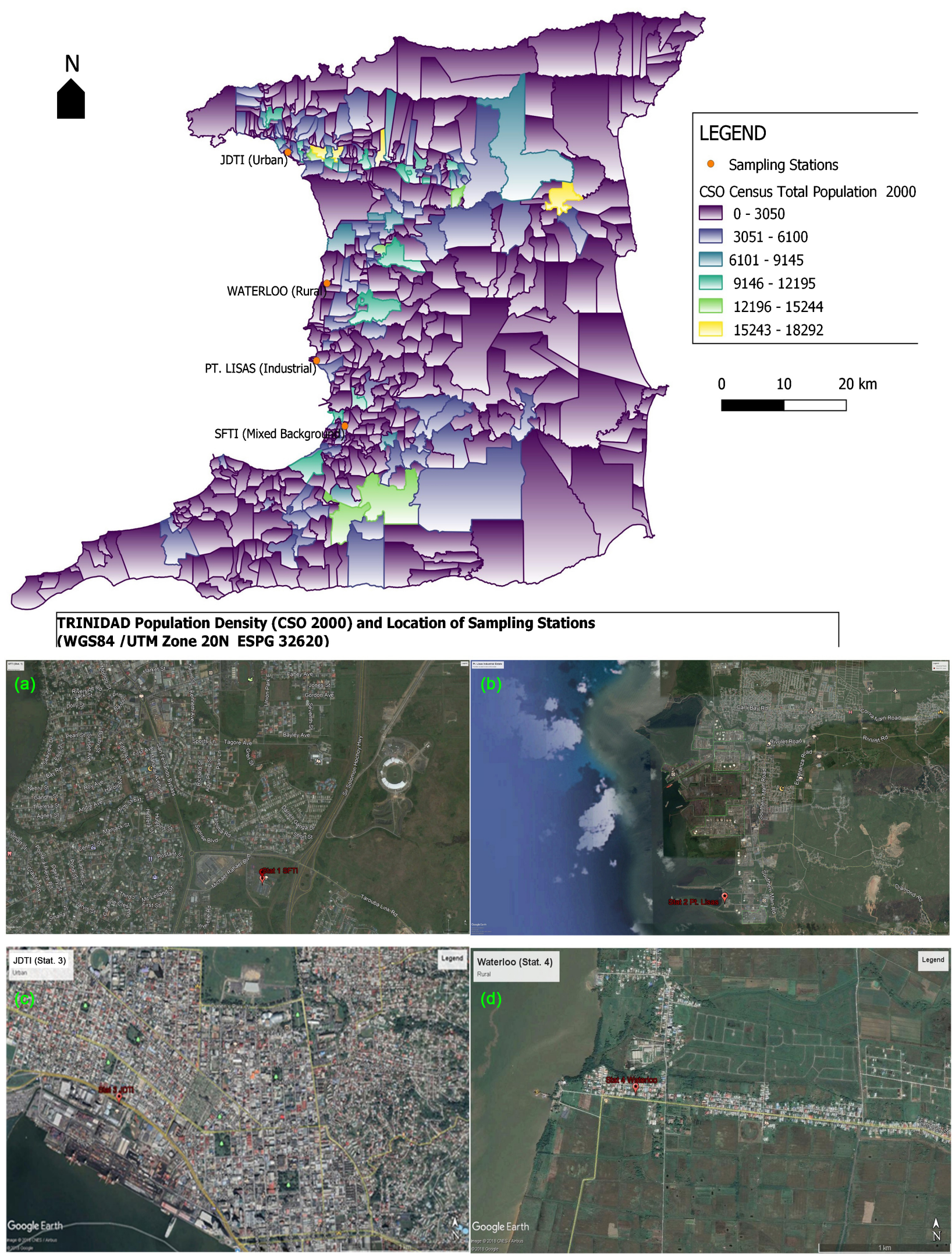

Figure 1. Location Map for ambient air particulates monitoring stations ((a) mixed background, (b) industrial, (c) urban, (d) rural) Trinidad illustrating population density (Central Statistical Office, T \& T, 2019). 
- INDUSTRIAL: Point Lisas (Station 2): 10.377N lat, 61.482W long.

The study was designed to assess the potential trace metal contaminants in ambient air that pose a threat to public health (illustrated in Figure 2). Several QA/QC strategies were employed in sample collection and laboratory protocols to minimize cross contamination from handling, storage, labware and reagents for accurate ICP-MS analysis of trace metals (Bruker, 2010; Hassan, 2007; US Environmental Protection Agency, 2005).

Particulates were collected on three tiers of desiccated (Secador Desiccator) and pre-weighed (Mettler Toledo XP26 microbalance-range $0.001 \mathrm{mg}$ to $22 \mathrm{~g}$ ) quartz fibre filters (collecting $\mathrm{PM}_{1}, \mathrm{PM}_{1-2.3}$ and $\mathrm{PM}_{2.5-10}$ ) using a combined head (ISAP 1050e PKPM 10 \& 2.5 \& 1.0/2.3 combination), low volume ( $\mathrm{Q}=2.3$ $\mathrm{m}^{3} / \mathrm{hr}$ ) programmable modular gravimetric cascade sampler (ISAP 1050e500) (compliant with German/EU air quality control regulations for limit values and measurement engineering 2008/50/EC, BimSchV, EN 12341, EN 14907, EN 481, ISO 8756, TA Luft, VDI 2463 BI. $1+8$ and VDI BI.2).

Flow rates were recorded in the sampling log and tallied for total volume of air sampled $\left(50-54 \mathrm{~m}^{3}\right)$ over the sampling timeframe $\left(24 \mathrm{hrs}\right.$ every $6^{\text {th }}$ day at four sampling sites). Particulate loading was determined by differential weighing of pre- and post-exposed desiccated filters. Filters were stored (folded in plastic sample bags) in the freezer until ready for digestion (Anton Paar Multiwave microwave digester).

Laboratory protocols followed the USEPA standard methods for digestion and ICP-MS analysis-USEPA Method 3501 and 6020A (US Environmental Protection Agency, 1998, 2005) with recommended adjustments during digestion for smaller acid volumes, longer digestion times and decreased ratio of sample mass to acid volume for microwave digestion (Hassan, 2007) and manufacturer's operational guidelines for the ICP-MS (Bruker, 2010) (listed in Table 1).

The samples were digested (Anton Paar Microwave Reaction System-Multiwave $\mathrm{PRO}$ oven) at $160^{\circ} \mathrm{C}$ for 30 minutes at $650 \mathrm{~W}$ using a solution of $3 \mathrm{ml}$ ultra-high purity nitric acid (Fisher ChemAlert OPTIMA Nitric Acid 65\% - 70\%) and $5 \mathrm{ml}$ UHP (18.2 M $\Omega$ ) water (Thermo Scientific Barnstead GenPure UHP Water Filtration System and centrifuged at $2500 \mathrm{rpms}$ for 20 minutes. Trace Metal Analysis

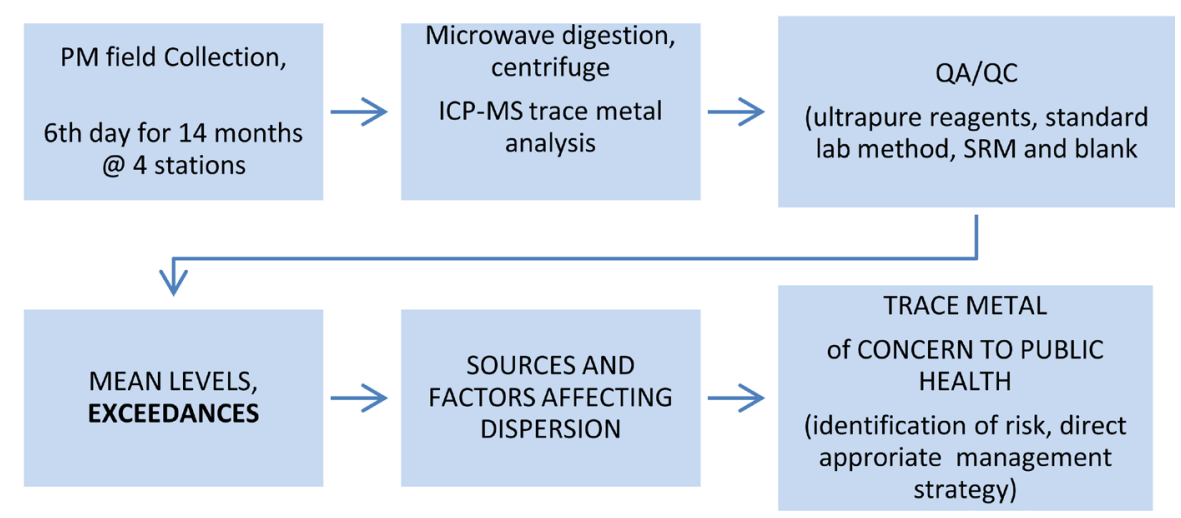

Figure 2. Schematic of study plan and objectives. 
Table 1. ICP-MS operating conditions for trace metal analysis.

\begin{tabular}{cc}
\hline ICP-MS Operating Parameter & Condition \\
\hline Sheath gas flow & $0.20 \mathrm{~L} / \mathrm{min}$ \\
Nebulizer flow & $1.00 \mathrm{~L} / \mathrm{min}$ \\
Plasma gas flow & $(15.0 \mathrm{~L} / \mathrm{min})$ \\
RF power & $(1.3 \mathrm{~kW})$ \\
Auxiliary gas flow & $1.85(\mathrm{~L} / \mathrm{min})$ \\
Reaction gas & Argon \\
Spray chamber & Quartz Peltier-cooled Scott-type @ 30C \\
Nebulizer & Micromist \\
Scan mode & Peak hopping \\
Cones & CRI skimmer cones \\
Reaction cell & Collision cell \\
Pump rate & $4 \mathrm{rpm}$ \\
Stabilization delay & 20 sec \\
Replication integrations & 5 \\
Mass range & 7.69 sec per replicate \\
Number of scan sweeps & $6.00 \mathrm{~mm}$ \\
Dwell time & $>0.99$ \\
Sampling depth & 10 \\
Calibration curves & \\
\hline & \\
\hline
\end{tabular}

was done using a Bruker Aurora 90 ICP-MS analyser and CETAC ASX-520 Autosampler with CETAC ENC500 Enclosure. Field blanks and standard reference materials filters (NIST Standard Reference Material 2783) were digested using the same analytical protocol as samples to determine blank concentrations and recoveries for trace metals for this study (listed in Table 2).

ICP-MS calibration and verification stock and standard solutions were prepared from $1 \mathrm{ml}$ of Plasma Cal $100 \mathrm{ug} / \mathrm{L}$ multi-element of premixed standard stock, diluted with the appropriate volume of digestion solution, in each case to $100 \mathrm{ml}$ using Class A polyethylene volumetric flasks. Standard solutions of 1 ppb, $10 \mathrm{ppb}, 50 \mathrm{ppb}$ and $100 \mathrm{ppb}$ were made up and used for calibration. The ICP-MS was optimised using the manufacturer supplied tuning solution (containing $10 \mathrm{ug} / \mathrm{L} \mathrm{Li}, \mathrm{Y}$ Ce and $\mathrm{Ti}$ in $1 \% \mathrm{HNO} 3$ ) to cover mass range of interest. The instrument was optimised daily prior to running the samples. An internal standard (of $1 \mathrm{mg} / \mathrm{L} \mathrm{Sc} 45, \mathrm{Y} 89$ and $\mathrm{Tb} 159$ in 5\% $\mathrm{HNO}_{3}$ ) was prepared from Plasma Cal single element solution. Analytical isotopes were selected from those recommended (US Environmental Protection Agency, 1998) for reliable concentration calculations (Table 2), or the most abundant isotopes with least interference.

All the isotopes for lead $(\mathrm{Pb})$ were measured collectively as a single output. Mercury ( $\mathrm{Hg}$ ) was measured semi-quantitatively as the ICP-MS was run in standard 
Table 2. Trace metal isotopes and \% recoveries in ICP-MS analysis.

\begin{tabular}{|c|c|c|c|c|}
\hline Element & $\begin{array}{l}\text { Isotope(s) } \\
\text { Measured }\end{array}$ & $\begin{array}{l}{ }^{\text {a Isotope }} \\
\text { (USEPA) }\end{array}$ & $\begin{array}{l}\text { Isotope Used in } \\
\text { this Study }\end{array}$ & $\begin{array}{l}\text { Recoveries \% Range } \\
\quad(\text { cf SRM } \pm 1 \text { SD) }\end{array}$ \\
\hline Arsenic & 75 & 75 & 75 & \\
\hline Barium & 137 & 137 & 137 & $84.4-95.2$ \\
\hline Beryllium & 9 & & 9 & \\
\hline Cadmium & $111,112,114$ & 111 & 111 & \\
\hline Calcium & 44 & & 44 & \\
\hline Caesium & 133 & & 133 & \\
\hline Chromium & 52,53 & & 52 & $90.8-91.7$ \\
\hline Cobalt & 59 & 59 & 59 & $94.7-102.1$ \\
\hline Copper & 63,65 & 63 & 63 & 59.7 \\
\hline Iron & 57 & & 57 & $115.7-131.0$ \\
\hline Lead & all & $206,207,208$ & $206,207,208$ & $111.4-122.8$ \\
\hline Lithium & 7 & & 7 & \\
\hline Magnesium & 24 & 24 & 24 & $108.0-113.1$ \\
\hline Manganese & 55 & 55 & 55 & \\
\hline Mercury & qualitative & & - & \\
\hline Nickel & 60 & 60 & 60 & $86.5-102.3$ \\
\hline Rubidium & 85 & & 85 & \\
\hline Selenium & 78 & 82 & 82 & \\
\hline Strontium & 88 & & 88 & \\
\hline Uranium & 238 & & 238 & \\
\hline Vanadium & 51 & 51 & 51 & $146.5-161.5$ \\
\hline Zinc & 66,68 & 66 & 66 & $69.7-70.6$ \\
\hline
\end{tabular}

aAdapted from (Rosman \& Taylor, 1999).

mode optimised for most of the measured elements. In this mode, levels of $\mathrm{Hg}$ are not measured with the same accuracy. Statistical data analysis using univariate general linear models to identify the significant independent variables affecting the pollutant concentration and exploratory factor analysis used to identify any natural groupings among them to narrow sources and co-emitted pollutants.

\section{Results and Discussion}

The mean levels of trace metals were calculated from summing concentrations in the three ambient air $\mathrm{PM}$ fractions (thus concentration in $\mathrm{PM}_{10}$ ) averaged over a specified 2-month period. Means were compared to reference local/international ambient air quality (AAQ) standards where available. Some trace metals did not exceed any of the local/international AAQ standards used (Environmental 
Management Authority of Trinidad and Tobago, 2014; Ontario-MoE, 2012) in any of the samples collected during this study. These "non-concerning" metals were caesium, cobalt, copper, mercury, lead, lithium, selenium, strontium, vanadium and zinc. Arsenic levels were below those prescribed in the Canadian guidelines, but this study found that the existent levels tended to predominate in the fine PM fraction.

The source of fine PM can be from gas-phase reactions, incineration/combustion processes or from transboundary Sahara dust. However, studies of the trace metals in Sahara dust (collected from a Tobago sampling station) indicated levels that were not significantly different from that contained in the comparative soil samples (Garrison et al., 2010).

The trace metals whose concentrations were found to exceed the prescribed AAQ reference standards for the protection of public health (Ontario-MoE, 2012) at least once during sampling were beryllium, cadmium, chromium, iron, manganese and nickel. The exceedance frequency was tallied for each trace metal, per station, per 2-month period (outlined in Table 3-exceedances highlighted in bold font). The data identified the industrial and urban sites as areas of concern, particularly during June-July '15 and February-March '16 where almost all the trace metals in exceedance occurred. The content of trace metals in each PM fraction is illustrated in Figures 3-8. Public health implications of these trace metals, particularly those found in exceedance AND in the finer particulates $\left(\mathrm{PM}_{2.5}\right)$ are more serious and require intervention as these are inhaled deeper and take longer to flush out of the lungs, increasing their toxicity.

Beryllium (Be) occurred predominantly in the coarse PM fraction $\left(\mathrm{PM}_{2.5-10}\right)$ with the highest concentrations measured at the mixed background site (Figure 3). Likely it originated as a raw material from an industrial process or resuspension from excavation works.

Cadmium (Cd) (notably highest at the rural site only within a limited time) likely reflects an irregular occurrence (Table 3). Its predominance in fine PM (Figure 4) hints at anthropogenic origin and is concerning as it is a genotoxic carcinogen with an indeterminate source (possibly as a consequence of a bush fire that occurred during the time of sampling), therefore warranting further investigation.

Chromium (Cr), with only two measured exceedances both at the industrial site (Table 3), is of public health concern as it occurs predominantly in the finest $\mathrm{PM}$ fraction $\left(\mathrm{PM}_{1}\right)$ and is carcinogenic (Figure 5). It is a frequent component of cooling water as well as raw material in industrial steel making, catalyst in industrial processes and rust-proof coating products.

Iron $(\mathrm{Fe})$ recorded exceedances at all four stations (Table 3). Concentrations were consistently high at the Pt. Lisas station for the entire duration of the study, peaking in June-July '15 and February-March '16, falling off in concentration, but still exceeding the limit $\left(4 \mu \mathrm{g} / \mathrm{m}^{3}\right)$ for safe public health exposure (Ontario-MoE, 2012). Iron is ubiquitous in the environment, however, being a natural crustal element and having multiple sources; including from natural 
H. Baboolal et al.

Table 3. Frequency of exceedances-trace metals in $\mathrm{PM}_{10}\left(\mu \mathrm{g} / \mathrm{m}^{3}\right)$ cf. Canadian AAQ (Ontario-MoE, 2012).

\begin{tabular}{|c|c|c|c|c|c|c|}
\hline Trace Element & AAQ Std & Station & Period & ${ }^{*}$ MEAN Conc. & MAX Conc & Freq. of Exceedance \\
\hline $\mathrm{Be}$ & 0.01 & mixed background & Dec'15-Jan '16 & 0.7199 & 0.71991 & 1 \\
\hline $\mathrm{Cd}$ & 0.025 & rural & Dec'15-Jan'16 & 0.0780 & 0.2887 & 1 \\
\hline $\mathrm{Cr}$ & 0.5 & industrial & Aug-Sep '15 & 0.5087 & 1.3739 & 2 \\
\hline \multirow[t]{21}{*}{$\mathrm{Fe}$} & 4.0 & mixed background & Apr-May '15 & 4.8475 & 9.7724 & 4 \\
\hline & & & Jun-Jul '15 & 5.9872 & 10.0369 & 3 \\
\hline & & & Oct-Nov'15 & 2.1701 & 4.9123 & 1 \\
\hline & & & Feb-Mar'16 & 5.0062 & 9.7566 & 2 \\
\hline & & & Apr-May '16 & 3.5332 & 5.6462 & 3 \\
\hline & & industrial & Apr-May '15 & 7.7154 & 12.3976 & 8 \\
\hline & & & Jun-Jul '15 & 14.5964 & 23.6514 & 6 \\
\hline & & & Aug-Sep '15 & 7.8894 & 13.8671 & 1 \\
\hline & & & Oct-Nov'15 & 4.2179 & 8.5112 & 2 \\
\hline & & & Dec'15-Jan '16 & 4.3730 & 6.3711 & 1 \\
\hline & & & Feb-Mar'16 & 9.7600 & 30.3154 & 5 \\
\hline & & & Apr-May '16 & 3.0583 & 5.9493 & 3 \\
\hline & & urban & Apr-May '15 & 4.4481 & 7.4274 & 5 \\
\hline & & & Jun-Jul '15 & 5.2448 & 7.7434 & 5 \\
\hline & & & Oct-Nov'15 & 2.4042 & 5.7618 & 1 \\
\hline & & & Dec'15-Jan '16 & 5.8757 & 10.5179 & 1 \\
\hline & & & Feb-Mar'16 & 4.5732 & 9.8423 & 3 \\
\hline & & & Apr-May'16 & 3.4882 & 6.6554 & 2 \\
\hline & & rural & Dec '15-Jan '16 & 3.0005 & 5.1647 & 1 \\
\hline & & & Feb-Mar'16 & 4.0983 & 8.3438 & 5 \\
\hline & & & Apr-May'16 & 2.5697 & 5.8767 & 2 \\
\hline \multirow[t]{12}{*}{$\mathrm{Mn}$} & 0.2 & mixed background & Apr-May'15 & 0.1029 & 0.2096 & 1 \\
\hline & & & Jun-Jul '15 & 0.1335 & 0.5216 & 1 \\
\hline & & & Feb-Mar'16 & 0.0230 & 0.8613 & 2 \\
\hline & & industrial & Apr-May '15 & 0.1541 & 0.2659 & 2 \\
\hline & & & Jun-Jul '15 & 0.3189 & 0.5216 & 4 \\
\hline & & & Aug-Sep '15 & 0.1722 & 0.3599 & 1 \\
\hline & & & Oct-Nov'15 & 0.1169 & 0.2062 & 1 \\
\hline & & & Feb-Mar'16 & 0.2897 & 0.8613 & 5 \\
\hline & & urban & Jun-Jul '15 & 0.2125 & 0.9536 & 1 \\
\hline & & & Dec'15-Jan'16 & 0.2663 & 0.2663 & 1 \\
\hline & & & Feb-Mar'16 & 0.1218 & 0.2697 & 1 \\
\hline & & rural & Feb-Mar'16 & 0.1250 & 0.2523 & 3 \\
\hline \multirow[t]{5}{*}{$\mathrm{Ni}$} & 0.1 & industrial & Jun-Jul '15 & 0.0706 & 0.1481 & 1 \\
\hline & & & Aug-Sep '15 & 0.2884 & 0.8237 & 1 \\
\hline & & & Feb-Mar'16 & 0.0711 & 0.3411 & 1 \\
\hline & & urban & Jun-Jul '15 & 0.0594 & 0.1804 & 1 \\
\hline & & rural & Feb-Mar'16 & 0.0311 & 0.1149 & 1 \\
\hline
\end{tabular}



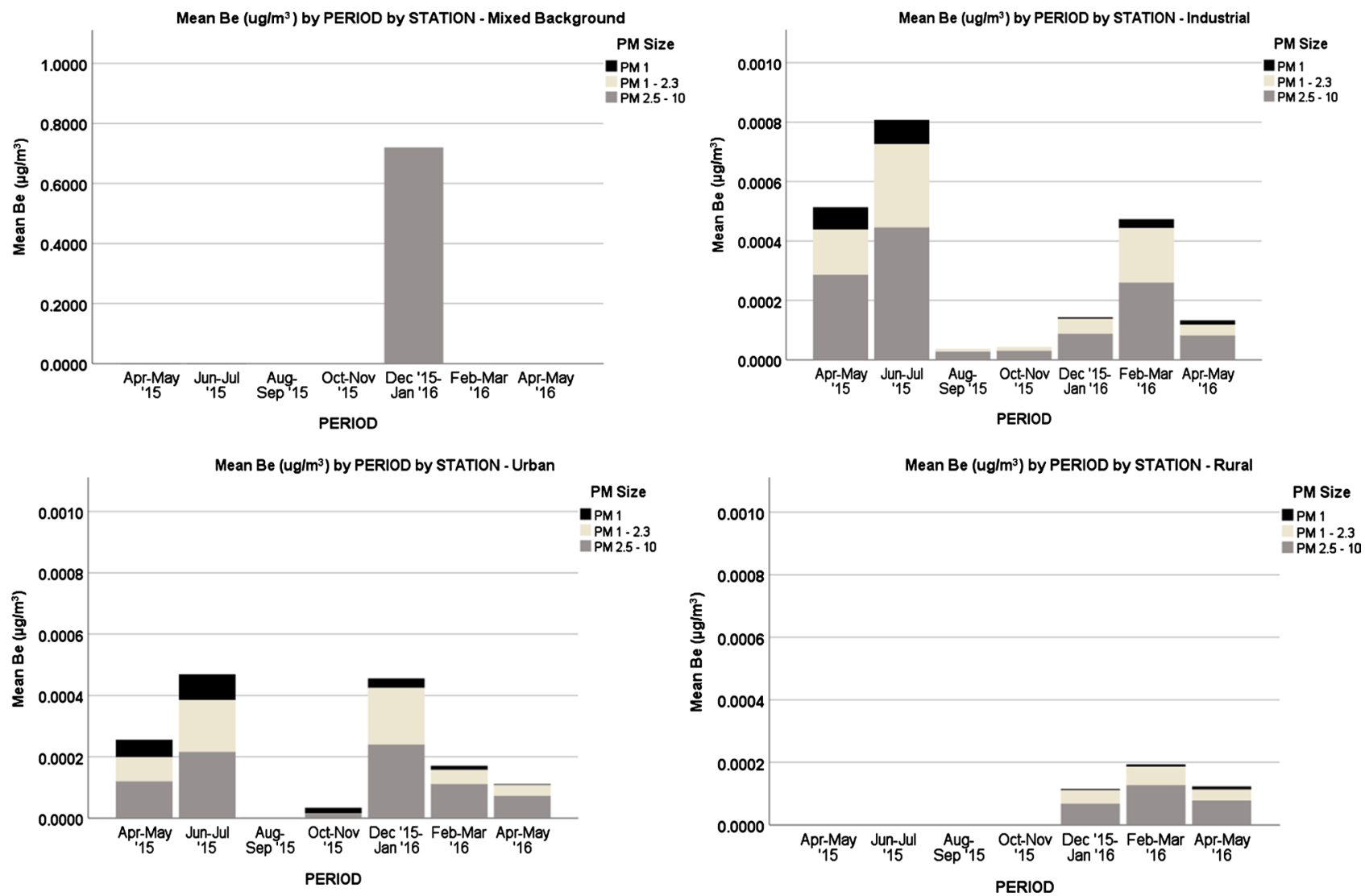

Figure 3. Beryllium in respirable PM at four sampling sites-AAQ Standard-0.01 $\mu \mathrm{g} / \mathrm{m}^{3}$ (Ontario-MoE, 2012).
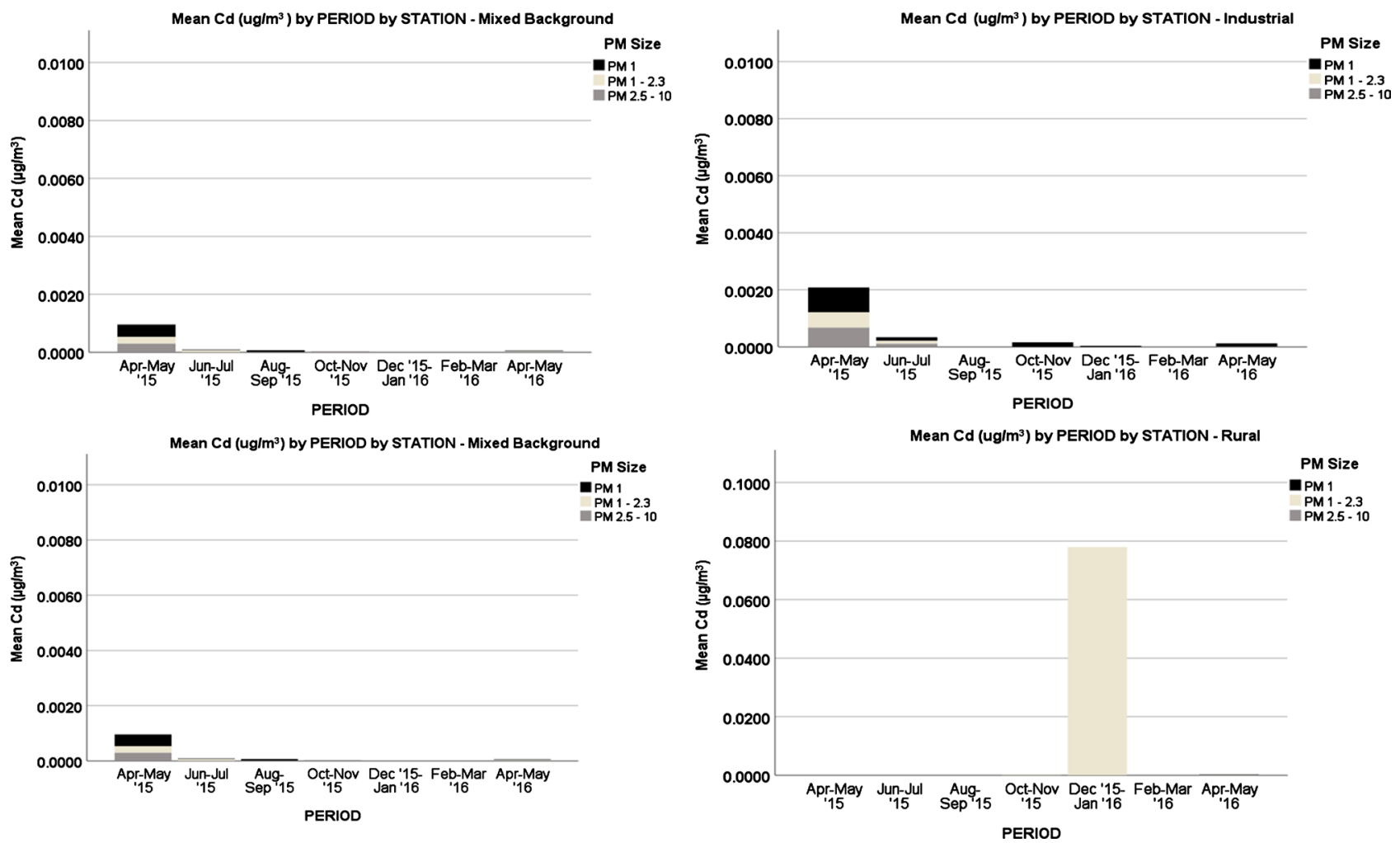

Figure 4. Cadmium in respirable PM at four sampling sites-AAQ Standard-0.025 $\mu \mathrm{g} / \mathrm{m}^{3}$ (Ontario-MoE, 2012). 

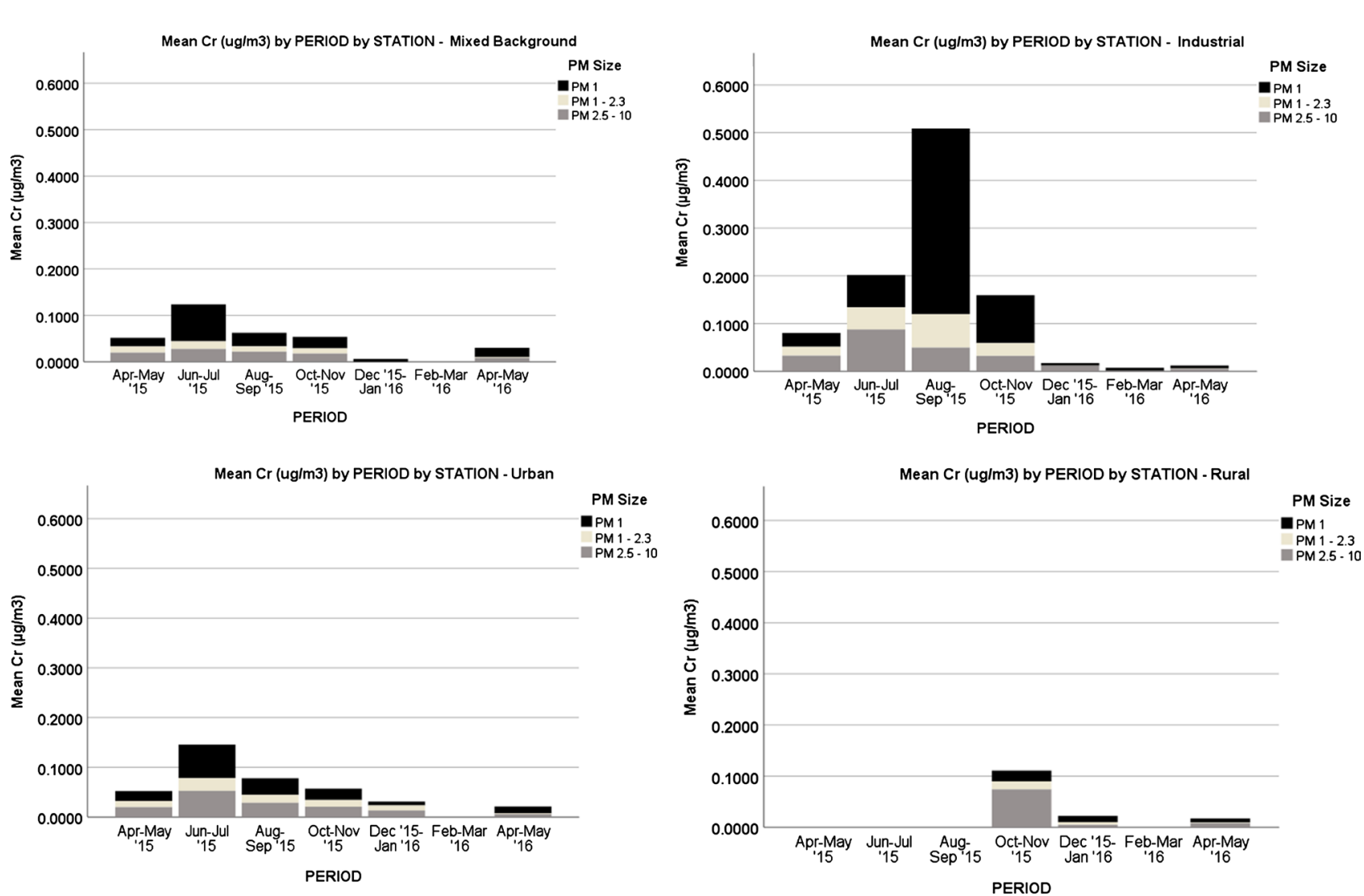

Figure 5. Chromium in respirable PM at four sampling sites-AAQ Standard-0.5 $\mu \mathrm{g} / \mathrm{m}^{3}$ (Ontario-MoE, 2012).

erosion, local iron and steel smelting industries and transboundary Sahara dust, high concentrations spread across varied PM size fractions were found as expected (Figure 6).

Manganese (Mn) had exceedances at all four stations (Table 3), but at a higher frequency at the industrial sampling site, particularly during periods June-July ' 15 and February-March '16. The highest mean concentrations of the element were measured at the industrial station during June-July '15. Most of it occurs in the coarse PM $\left(\mathrm{PM}_{2.5-10}\right)$ (Figure 7), point to likely sources such as raw material inputs for the nearby iron and steel processing plants and the cement factories. The urban sources are significant and contribute to relatively high concentrations as well, notably in June-July ' 15 and December '15-January ' 16 . These are the seasonal transition months so there may be a linkage to climatic conditions at those times.

Nickel (Ni) is of most concern as a threat to public health. Five exceedances were recorded during sampling, most at the industrial site (Table 3). It is predominantly used in alloy and steel making. Most of the Ni measured during exceedances were recorded with elevated levels of $\mathrm{Ni}$ in the fine $\mathrm{PM}$ fraction $\left(\mathrm{PM}_{2.5}\right)$ (Figure 9), which is the dominant form this element was measured in ambient air in this study. It peaked in the same PM fraction at the rural station, indicating a possible common source for both the $\mathrm{Cd}$ and $\mathrm{Ni}$ contamination at the rural station during Dec '15-Jan '16 period. Nickel and Cr also show similar 

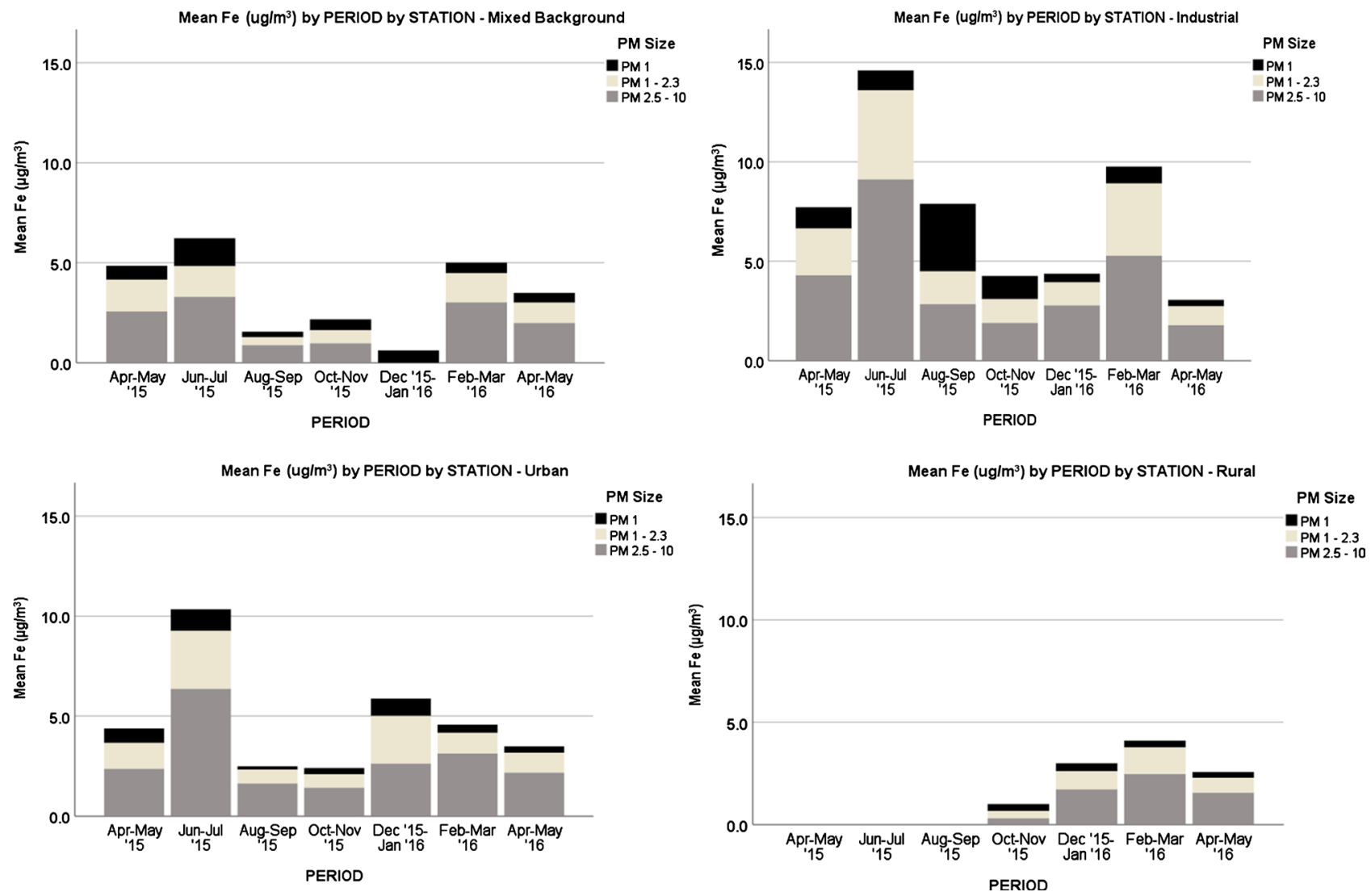

Figure 6. Iron in respirable PM at four sampling sites-AAQ Standard-4.0 $\mu \mathrm{g} / \mathrm{m}^{3}$ (Ontario-MoE, 2012).
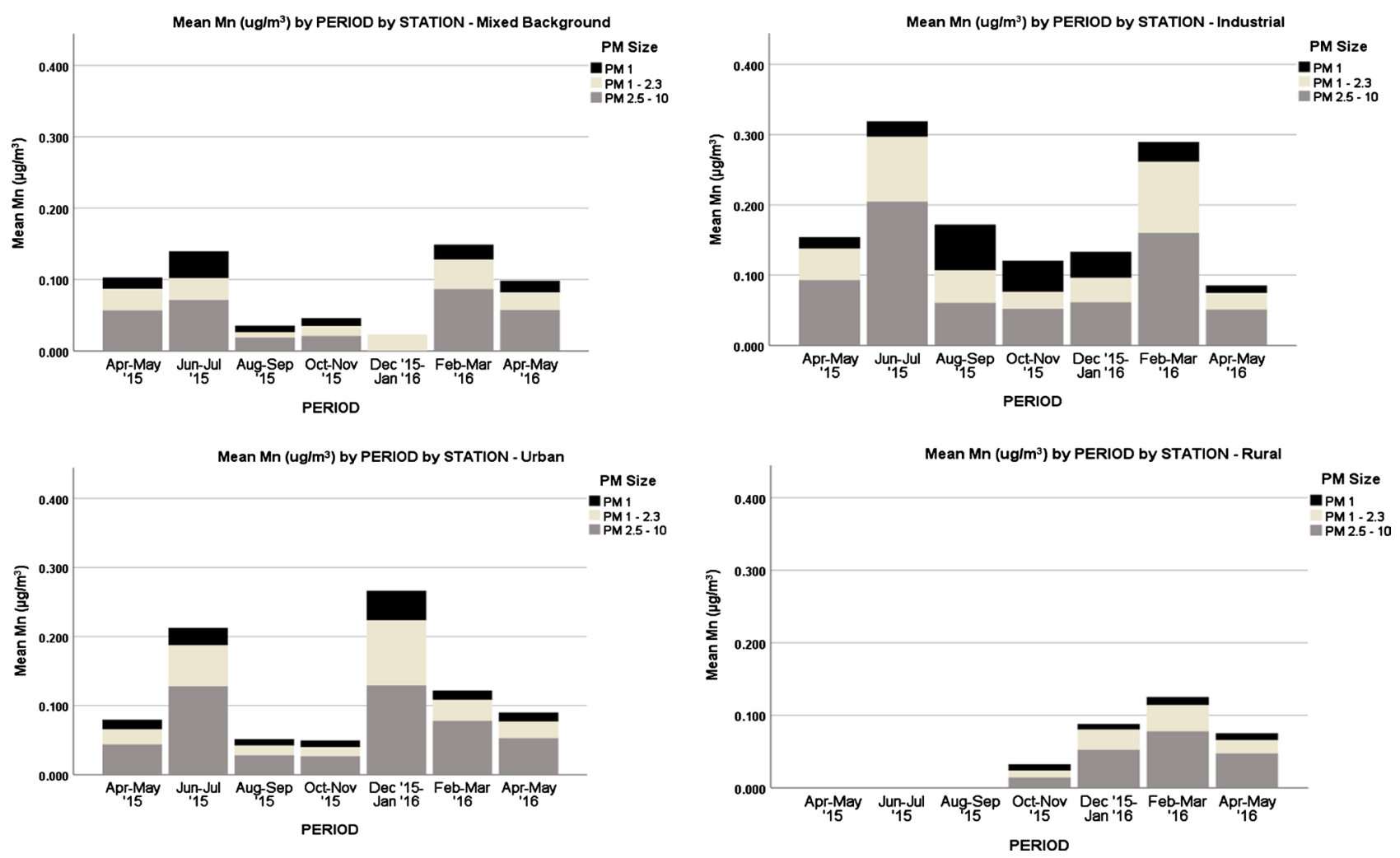

Figure 7. Manganese in respirable PM at four sampling sites-AAQ Standard- $0.2 \mu \mathrm{g} / \mathrm{m}^{3}$ (Ontario-MoE, 2012). 

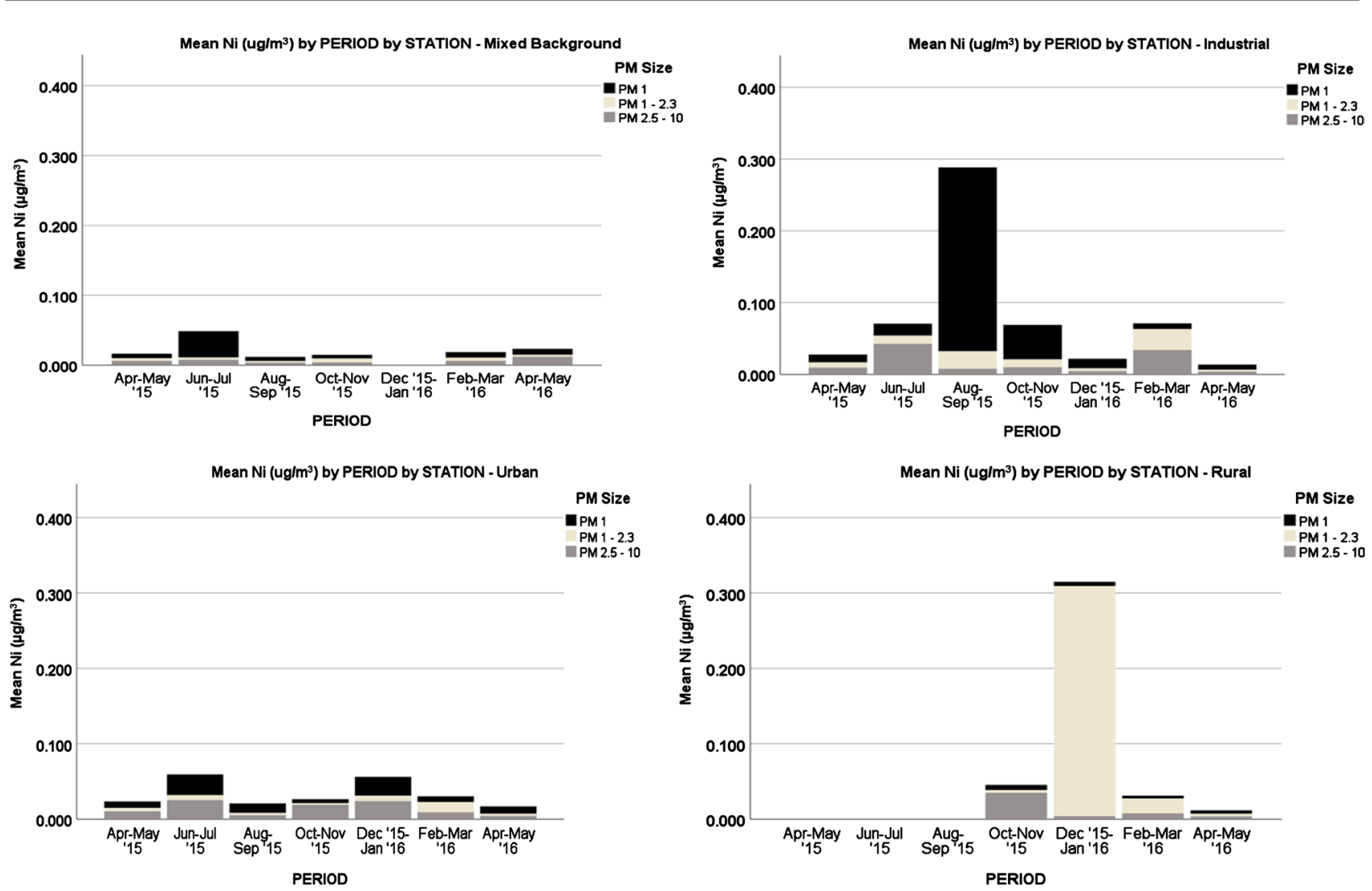

Figure 8. Nickel in respirable PM at our sampling sites-AAQ Standard-0.1 $\mu \mathrm{g} / \mathrm{m}^{3}$ (Ontario-MoE, 2012).

peaks in the $\mathrm{PM}_{1}$ fraction at the industrial station. The genotoxicity of $\mathrm{Ni}$ and its predominance in the fine PM requires that action be taken to regulate the emission of this pollutant in the atmosphere to prevent unnecessary exposure to this carcinogen.

\subsection{Statistics: Exploratory Factor Analysis}

The variables affecting the levels of trace metals as identified by the GLM analyses varied by metals. They included location, time of year and particulate size as the significant variables. Exploratory Factor Analysis was used to condense the trace metal concentrations and their patterns of covariance to a smaller number of underlying (unobserved) dimensions present in the dataset (the entire suite of trace metals in the three PM sizes at the four sampling stations over the sampling period) which are represented by the factors extracted. The purpose of applying this technique to this study is to better understand trends and interpret results since the factors extracted can then be analysed to determine the variables that impact the natural groupings and to make assertions as to why these trace metals group together (e.g. co-emissions, similar source).

Varimax rotation was applied to produce orthogonal factors, with factor loadings of 0.6 or greater considered as substantial. The component matrix for the exploratory factor analysis for the trace metal data yielded a five factor (Varimax with Kaiser normalisation) solution (Table 4). The factor solution accounted 
Table 4. Factor analysis of trace metals-component score matrix.

\begin{tabular}{|c|c|c|c|c|c|}
\hline \multirow[t]{2}{*}{ Factors } & \multicolumn{5}{|c|}{ Exploratory Factor Analysis (72.7\% Variance) } \\
\hline & Factor 1 & Factor 2 & Factor 3 & Factor 4 & Factor 5 \\
\hline$\%$ Variance & 35.2 & 12.9 & 9.2 & 8.8 & 6.6 \\
\hline \multirow[t]{8}{*}{ Elements-loadings } & Sr-0.959 & $\mathrm{Ni}-0.879$ & Cd-0.841 & Se- 0.672 & $\mathrm{Zn}-0.870$ \\
\hline & $\mathrm{Mn}-0.056$ & $\mathrm{Cr}-0.846$ & V-0.827 & $\mathrm{Pb}-0.646$ & \\
\hline & Fe-0.953 & $\mathrm{Hg}-0.689$ & & As- 0.607 & \\
\hline & Be-0.925 & & & & \\
\hline & Ba- 0.864 & & & & \\
\hline & Co- 0.804 & & & & \\
\hline & Cs-0.789 & & & & \\
\hline & $\mathrm{Mg}-0.649$ & & & & \\
\hline Possible sources & $\begin{array}{l}\text { Crustal elements, iron smelting, } \\
\text { vehicles, cement manufacture, oil } \\
\text { and gas }\end{array}$ & Steel and metal alloys & Slag, electroplating & Metalloids & $\begin{array}{c}\text { Crustal element, roofing, } \\
\text { vehicles, coatings }\end{array}$ \\
\hline \multirow{5}{*}{$\begin{array}{c}\text { Parameters of the } \\
\text { analysis }\end{array}$} & \multicolumn{3}{|c|}{-Kaiser-Meyer-Olkin Measure of Sampling Adequacy. } & \multicolumn{2}{|l|}{0.804} \\
\hline & \multicolumn{3}{|l|}{-Bartlett's Test of Sphericity } & \multicolumn{2}{|l|}{1925.5} \\
\hline & \multicolumn{3}{|l|}{ Approx. Chi-square } & \multicolumn{2}{|l|}{153} \\
\hline & \multicolumn{3}{|l|}{ df } & \multicolumn{2}{|l|}{0.00} \\
\hline & Significance $(p)$ & & & & \\
\hline
\end{tabular}

for $72.7 \%$ of the variance with each trace metal loading onto only one factor with component scores $>0.6$ (except for $\mathrm{Cu}$ which could not load onto one factor and was not included in the solution). The high KMO score of 0.804 for sample adequacy and a significant $(p<0.05)$ Bartlett's test of sphericity indicate that the factor solution is a good fit for the data.

Factors 1 and 2 constructs were the most prominent, accounting for 35.2\% and $12.9 \%$ of the dataset variance respectively. The metal grouping in Factor 1 contains elements which are prominent in coarse PM, includes iron and manganese which occur together naturally in mineral ores and is important input for iron smelting and steel production. These two elements with the highest frequency of exceedances in $\mathrm{PM}_{10}$ in this study have common sources. Barium is typically used as an additive to cast iron and steel to reduce the size of the carbon grains within the microstructure, as well as an insoluble additive to drilling fluid oils. This factor also includes two trace metals caesium and beryllium which are associated entirely with anthropogenic activities; caesium in drilling muds for oil and gas exploration, and beryllium in the production of alloys used to manufacture springs, electrical contacts, non-sparking tools and spot-welding electrodes locally. Nickel and chromium group together in Factor 2, possibly reflecting the commonality of source from similar industrial use(s). Locally, these elements are used in the steel alloy and coatings manufacture. Factor 3 elements cadmium and vanadium have multiple uses including electroplating on iron and steel prod- 
ucts to improve corrosion resistance.

\subsection{Wind and Precipitation}

Particulates dispersion in ambient air is affected by meteorological conditions, particularly wind, temperature and precipitation, as well as topographical features which determine general air flow. With seasonal patterns and local scale meteorological influences superimposed, pollutant dispersion can be complex. The wind fields generated from sampling stations showed a migration of the predominant easterly winds over the study period, significantly different from the predominant winds measured at the national weather station at Piarco International Airport (10.58N, 61.35W).

The industrial station which measured the most frequent exceedances has a variable wind field (illustrated in Figure 9). The direction from which the dominant winds blew varied during the study period and may account for the high levels of some of the trace metals measured in June-July '15 period. In June-July ' 15 (Figure 9(a)), the dominant winds came from the northeast across the entire industrial estate (the sampling station was located on the southern periphery of the industrial estate). By December '15-January '16 (Figure 9(d)), the wind field was much narrower, predominantly southeast, but measured the highest frequency of sluggish winds ( $9.9 \%$ of measurements were $<1.54 \mathrm{~m} / \mathrm{sec}$ ) and the lowest frequency of higher speed winds, indicating slower and unidirectional movement of air with pollution loading coming from sources downwind of the industrial estate, mostly residential and agricultural land use areas.

\subsection{Public Health Impact}

Fine PM in ambient air can originate from local gas-phase reactions, fuel incineration/combustion processes, vehicle exhaust, grassfires as well as transboundary Sahara dust. Studies of the trace metals in Sahara dust (collected from a Tobago sampling station) indicated levels that were not significantly different from that contained in the comparative soil samples (Garrison et al., 2010). Nickel and chromium featured prominently in the fine sediment contaminants of the riverine systems in Trinidad indicating that this is an important sink for these metals (Surujdeo-Maharaj, 2010). Studies on nearshore marine and coastal sediments however indicate significant levels of trace metals particularly on Trinidad's west coast (Mohammed et al., 2011; Norville, 2019). The inference is therefore that there are significant streams of waste containing trace metals emanating from Trinidad's west coast. The trace metals can come from burning materials contaminated with the trace metals (such as $\mathrm{Cd}$ in the bush fires at Waterloo) or from iron, steel and alloy smelting \& recovery plants and cement plants (such as at Pt. Lisas), or traffic emissions and erosion from vehicles (such as in Port-of-Spain and San Fernando).

Several trace elements are genotoxic, meaning there is no "safe exposure level". Arsenic is genotoxic and was predominantly found in the fine PM fraction in the ambient air locally. Levels measured in this study $\left(0.00-0.015 \mu \mathrm{g} / \mathrm{m}^{3}\right)$ were 

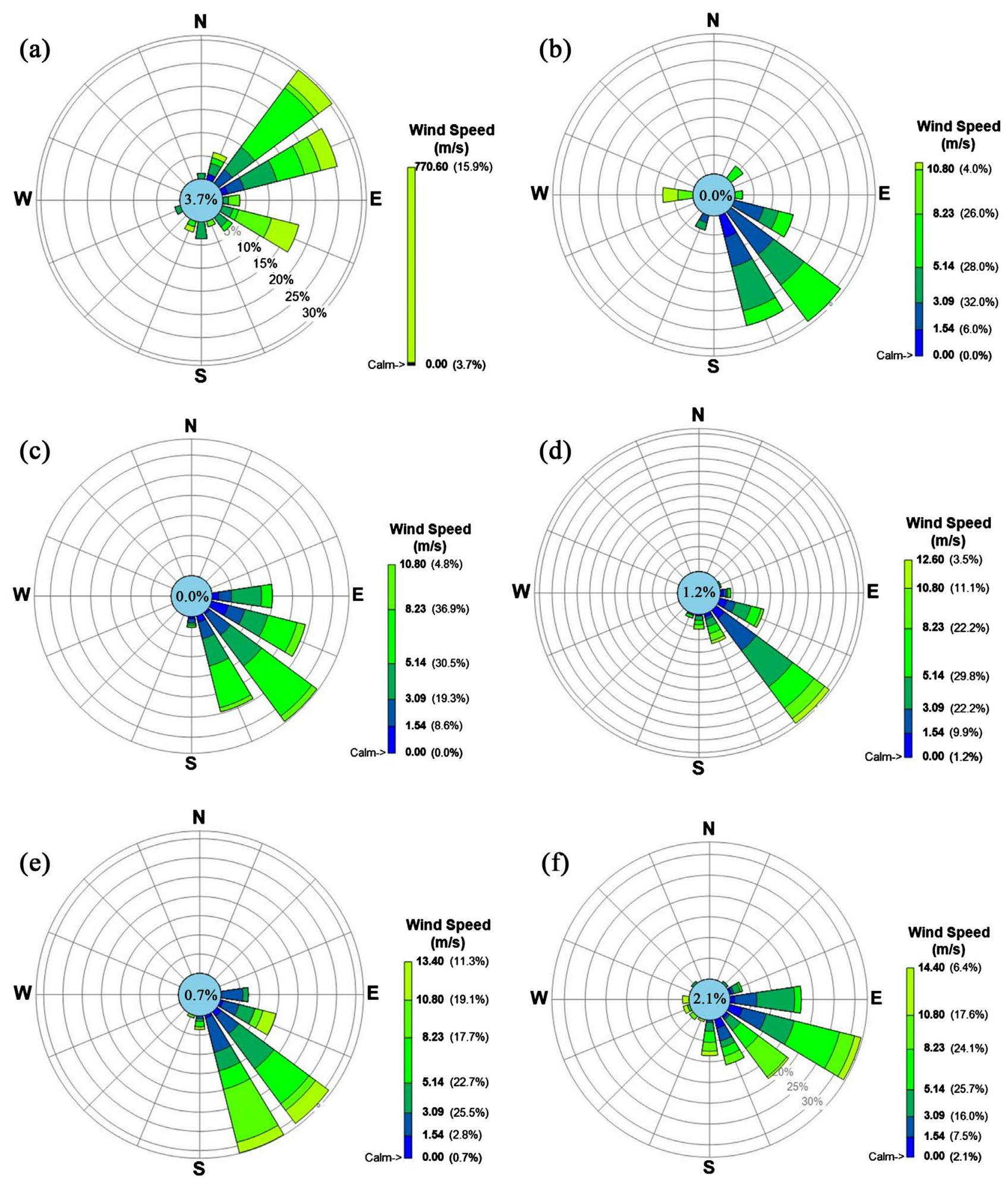

Figure 9. Wind rose plots-industrial station ((a) Jun-Jul '15; (b) Aug-Sep '15; (c) Oct-Nov '15; (d) Dec '15-Jan '16; (e) Feb-Mar '16 (f) Apr-May'16).

relatively on par with typical levels measured in the ambient air in the UK (1 - 5 and $5-10 \mathrm{ng} / \mathrm{m}^{3}$ in rural and urban locations; and up to $0.002-2.3 \mu \mathrm{g} / \mathrm{m}^{3}$ at industrial sites and non-ferrous smelting facilities) (DEFRA, 2008; European Com- 
mission, 2001), but were below the Canadian public health standards (Ontario-MoE, 2012) used for comparison in this study, and therefore not regarded as a major public health concern.

This study found that two of these; chromium and nickel; exist at levels that might be harmful. In many cases where it doesn't cause a disease, it often adds to the burden of disease, such that it worsens asthma symptoms in people so prone, exacerbates crises from cardio-vascular complications and COPD increases in occurrence and mortality from lung cancer. Management strategies here have to consider the costs involved in regulation vs the non-regulated scenario and the human health components.

The magnitude of the economic and social benefits to be had (Trejo-Gonzalez et al., 2019) from addressing the air pollution issues and alleviating the burden of disease on children, the workforce and the general population is the current general policy push to get action from regulators (World Health Organisation, Regional Office for Europe, 2019; United Nations Children's Fund, 2017). The elements that exist in concentrations that exceed limits for the protection of public health, the higher the concentrations of the elements in the finer particulates, the greater the detrimental health impact. The findings also suggest that there is avenue for epidemiological work (Gowrie, Agard, Barclay, \& Mohammed, 2016; Lipferta \& Wyzgab, 2019) in identifying cancer clusters in the non-smoking exposed population due to chronic exposure to air pollutants.

With regard to management, several of the trace metals detected in this study are co-emitted, such as $\mathrm{Fe}$ and $\mathrm{Mn}$, therefore, controlling for the particulate emissions (point source and fugitive emissions) at the industrial site can have the adjunct effect of controlling the trace metals contained in them (such as the Factor 1 trace elements). The particulates containing the trace metals also carry other chemicals substances that may pose harm. The maximum benefit would be gained by reducing the levels of overall fine and respirable articulates in the ambient air.

\section{Conclusion}

- Iron, manganese and nickel are the trace metals with the highest frequency of exceedance of the Canadian public health protection guidelines regulating contaminants in ambient air; chromium, beryllium and cadmium also exceeded these guidelines but less frequently (once or twice during sampling).

- The data clearly point to nickel as being very "concerning" as it is genotoxic, is prevalent in the finest PM fraction in ambient air and is frequently in exceedance.

- Management of co-emitted pollutants (Fe \& $\mathrm{Mn} ; \mathrm{Ni} \& \mathrm{Cr}$ ) will have the adjunct effect of reducing the particulate and trace metal loading in the ambient air.

- Continuous monitoring at rural and industrial sites is required to corroborate pollutant concentrations in the ambient air and to trace the effectiveness 
of any sector regulation and management strategies implemented to curb the pollution.

- Overall reduction of fine particulates in the ambient air would have the most impact on reducing negative health effects on the exposed public.

\section{Acknowledgements}

Research and costs associated with this study were funded by BPTT in conjunction with the University of Trinidad and Tobago under the BPTT PhD Research Fellowship programme.

\section{Conflicts of Interest}

The authors declare no conflicts of interest regarding the publication of this paper.

\section{References}

Balluz, L., Wen, X.-J., Town, M., Shire, J. D., Qualter, J., \& Mokdad, A. (2007). Ischemic Heart Disease and Ambient Air Pollution of Particulate Matter 2.5 in 51 Counties in the United States. Public Health Reports, 122, 626-633. https://doi.org/10.1177/003335490712200510

Bruker (2010). Preparing Your Laboratory for a Bruker 810-MS or 820-MS ICP Mass Spectrometer. Bremen: Bruker Daltonik GmbH.

Bruske, I., Hampel, R., Ruckerl, R., Schneider, A., Heinrich, A., Oberdorster, G., Peter, A. et al. (2010). Impact of Ambient Air Pollution in the Differential White Blood Cell Count in Patients with Chronic Pulmonary Disease. Inhalation Toxicology, 22, 245-252. https://doi.org/10.3109/08958370903207274

Central Statistical Office, T \& T (2019). 2000 Census Data. Ministry of Planning and Sustainable Development. http://cso.gov.tt/census/2000-census-data

DEFRA (2008). Expert Panel on Air Quality Standards: Consultation on Guidelines for Metals and Metalloids in Ambient Air for the Protection of Human Health. London: Department for Environment, Food and Rural Affairs. https://uk-air.defra.gov.uk/assets/documents/reports/cat11/0805151602_Metals_and_ Metalloids_Report.pdf

Dockery, W., Pope III, C. A., Xu, X., Spengler, J. D., Ware, J. H., Fay, M. E., Speizer, F. E. et al. (1993). An Association between Air Pollution and Mortality in Six US Cities. The New England Journal of Medicine, 329, 1753-1759. https://doi.org/10.1056/NEJM199312093292401

Environmental Management Authority of Trinidad and Tobago (2014). Republic of Trinidad and Tobago-The Environmental Management Act 35:05 Rules: Air Pollution Rules 2013.

European Commission (2001). Ambient Air Pollution by As, Cd and Ni Compounds-Position Paper Final Version. http://ec.europa.eu/environment/air/pdf/pp_as_cd_ni.pdf

Garrison, V. H., Foreman, W. T., Genualdi, S., Griffin, D. W., Kellogg, A. C., Majewski, M. S., Smith, G. W. et al. (2006). Saharan Dust-A Carrier of Persistent Organic Pollutants, Metals and Microbes to the Caribbean? International Journal of Tropical Biology, 54, 9-21.

Garrison, V., Lamothe, P., Morman, S., \& Plumlee, G. (2010). Trace-Metal Concentrations in African Dust: Effects of Long-Distance Transport and Implications for Human 
Health. In 19th World Congress on Soil Science-Soil Solutions for a Changing World (pp. 33-36). Brisbane, Australia: Published on DVD.

Geiger, A., \& Cooper, J. (2010). Appendix C: Overview of Airborne Metals Regulations, Exposure Limits, Health Effects, and Contemporary Research. https://www3.epa.gov/ttnemc01/prelim/otm31appC.pdf

Gowrie, M., Agard, J., Barclay, G., \& Mohammed, A. (2015). Forecasting Emergency Paediatric Asthma Hospital Admissions in Trinidad and Tobago: Development of a Local Model Incorporating the Interactions of Airborne Dust and Pollen Concentrations with Meteorological Parameters and a Time-Lag Factor. Open Journal of Air Pollution, 5, 109-126. https://doi.org/10.4236/ojap.2016.54009

Grahame, T., \& Schlesinger, R. (2010). Cardiovascular Health and Particulate Vehicular Emissions: A Critical Evaluation of the Evidence. Air Quality, Atmosphere, and Health, 3, 3-27. https://doi.org/10.1007/s11869-009-0047-x

Griffin, D. W. (2007). Atmospheric Movement of Microorganisms in Clouds of Desert Dust. Clinical Microbiology Reviews, 20, 459-477. https://doi.org/10.1128/CMR.00039-06

Hassan, N. P.-Z. (2007). Analysis of Environmental Samples Using Microwave-Assisted Acid Digestion and Inductively Coupled Plasma Mass Spectrometry: Maximising Total Element Recoveries. Water Air Soil Pollution, 178, 323-334. https://doi.org/10.1007/s11270-006-9201-3

Khanna, I., Khare, M., \& Gargava, P. (2015). Health Risks Associated with Heavy Metals in Fine Particulate Matter: A Case Study in Delhi City, India. Journal of Geoscience and Environment Protection, 3, 72-77. https://doi.org/10.4236/gep.2015.32012

Lepeule, J., Laden, F., Dockery, D., \& Schwartz, J. (2012). Chronic Exposure to Fine Particles and Mortality: An Extended Follow-Up of the Harvard Six Cities Study from 1974 to 2009. Environmental Health Perspectives, 120, 965-971. https://doi.org/10.1289/ehp.1104660

Lipferta, F., \& Wyzgab, R. (2019). Longitudinal Relationships between Lung Cancer Mortality Rates, Smoking, and Ambient Air Quality: A Comprehensive Review and Analysis. Critical Reviews in Toxicology, 49, 790-818.

https://doi.org/10.1080/10408444.2019.1700210

Mahowald, N., Hamilton, D., Mackey, K., Moore, J., Baker, A., \& Scanza, R. A. (2018). Aerosol Trace Metal Leaching and Impacts on Marine Mircoorganisms. Nature Communications, 9, 1-15. https://doi.org/10.1038/s41467-018-04970-7

Mohammed, A., May, T., Echols, K., Walther, M., Manoo, A., Maraj, D., Orazio, C. et al. (2011). Metals in Sediments and Fish from Sea Lots and Point Lisas Harbors, Trinidad and Tobago. Marine Pollution Bulletin, 64, 169-173.

https://doi.org/10.1016/j.marpolbul.2011.10.036

Monteil, M. A., Gyan, K., Henry, W., Lacaille, S. L.-E., McKay, S., \& Antoine, R. M. (2005). African Dust Clouds Are Associated with Increased Paediatric Asthma Accident and Emergency Admissions on the Caribbean Island of Trinidad. International Journal of Biometeorology, 49, 371-376. https://doi.org/10.1007/s00484-005-0257-3

Norville, W. (2019). Fractionation of Trace Metals in Coastal Sediments from Trinidad and Tobago, West Indies. Marine Pollution Bulletin, 150, Article ID: 110774.

Ontario-MoE (2012). Ontario’s Ambient Air Quality Criteria PIBS \# $6570 e 01$. http://www.airqualityontario.com/downloads/AmbientAirQualityCriteria.pdf

Pinto, E., Soares, C., Couto, C., \& Almeida, A. (2015). Trace Elements in Ambient Air at 
Porto Metropolitan Area-Checking for Compliance with New European Union (EU) Air Quality Standards. Journal of Toxicology and Environmental Health, Part A, 78, 848-859. https://doi.org/10.1080/15287394.2015.1051177

Rosman, K., \& Taylor, P. (1999). 1997 Report of the IUPAC Subcommittee for Isotopic Abundance Measurements. Pure and Applied Chemistry, 71, 1593-1607.

Surujdeo-Maharaj, S. (2010). Heavy Metals in Rivers of Trinidad and Tobago. PhD Thesis, St. Augustine: The University of Trinidad and Tobago, Department of Life Sciences.

Trejo-Gonzalez, A., Riojas-Rodriguez, H., Texcalac-Sangrador, J., Guerrero-Lopez, C., Cervantes-Martinez, K., Hurtado-Diaz, M., \& Sierra-de-la-Vega, L. A.-B. (2019). Quantifying Health Impacts and Economic Costs of PM2.5 Exposure in Mexican Cities of the National Urban System. International Journal of Public Health, 64, 561-572. https://doi.org/10.1007/s00038-019-01216-1

United Nations Children's Fund (2017). Danger in the Air: How Air Pollution Can Affect Brain Development in Young Children.

https://www.unicef.org/press-releases/babies-breathe-toxic-air-south-asia

US Environmental Protection Agency (1998). METHOD 6020A ICP-MS. http://www.caslab.com/EPA-Methods/PDF/EPA-Method-6020A.pdf

US Environmental Protection Agency (2005). Standard Operating Procedure for the Determination of Metals in Ambient Particulate Matter Analyzed by Inductively Coupled Plasma/Mass Spectrometry (ICP/MS).

https://www.epa.gov/sites/production/files/2015-07/documents/epa-6020a.pdf

Utsunomiya, S., Jensen, K., \& Keeler, G. A. (2004). Direct Identification of Trace Metals in Fine and Ultrafine Particles in the Detroit Urban Atmosphere. Environmental Science and Technology, 38, 2289-2297. https://doi.org/10.1021/es035010p

World Health Organisation, Regional Office for Europe (2019). Non-Communicable Diseases and Air Pollution. In WHO European High-Level Conference on Non-Communicable Diseases (p. 28). Denmark: WHO Regional Office for Europe.

http://www.euro.who.int/en/media-centre/events/events/2019/04/WHO-conference-N CDs-Ashgabat-2019/documentation/time-to-deliver-in-europe--meeting-noncommuni cable-disease-targets-to-achieve-the-sustainable-development-goals-2019

Zhang, L., Jin, X., Johnson, A., \& Gies, J. (2016). Hazard Posed by Metals and as in PM2.5 in Air of Five Megacities in the Beijing-Tianjin-Hebei Region of China during APEC. Environmental Science and Pollution Research, 23, 17603-17612. https://doi.org/10.1007/s11356-016-6863-2 